\title{
Candona alchichica (Podocopida: Candonidae), a new ostracod species from saline, tropical Lake Alchichica, Mexico
}

\author{
Sergio COHUO,${ }^{1 *}$ María del Carmen HERNÁNDEZ, ${ }^{2}$ Liseth PÉREZ, ${ }^{3}$ Javier ALCOCER ${ }^{4}$
}

${ }^{1}$ Institut für Geosysteme und Bioindikation, Technische Universität Braunschweig, Langer Kamp 19c D-38106 Braunschweig, Germany; ${ }^{2}$ Universidad Nacional Autónoma de México, Programa de Posgrado en Ciencias del Mar y Limnología, México; ${ }^{3}$ Universidad Nacional Autónoma de México, Instituto de Geología. Circuito Institutos. Ciudad Universitaria, Delegación Coyoacán. C.P. 4510, Ciudad de México, México; ${ }^{4}$ Universidad Nacional Autónoma de México, Facultad de Estudios Superiores Iztacala, Proyecto de Investigación en Limnología Tropical, Av. de los Barrios No. 1, Los Reyes Iztacala, 54090 Tlalnepantla, Estado de México, México

*Corresponding author: sergiocd@comunidad.unam.mx

\begin{abstract}
In North America, most species of the Candonidae family belong to the genus Candona. These species are frequently found in freshwater ecosystems and in sediment sequences, which makes them valuable tools for paleoenvironmental reconstructions. Knowledge of Mexican Candona species is limited, however, and scant information exists regarding their taxonomy and ecology. Here we describe Candona alchichica, a new ostracod species we suggest being endemic to Lake Alchichica, central Mexico. The species belongs to the acuminata group of species, based on the presence of 5+1 setae on the second segment of the mandibular palp. It is closely related to C. patzcuaro, C. tahoensis and C. ohioensis, but differs from those species in that the females have an elongated genital field, wide at the base and narrow at the end. Males have elongated hook-like prehensile palps and a particular arrangement of lobes in the hemipenis, i.e., the a-lobe is inclined with a digitiform basal projection, the b-lobe is distally rounded and the h-lobe is square-shaped and exceeding the length of the b-lobe. Candona alchichica $n$. sp. and C. patzcuaro display very similar shells in length and morphology, which can cause confusion if identification is carried out in the absence of soft parts, a common situation when dealing with carapace and valve remains in sediment cores. Detailed morphometric analyses, however, revealed a clear difference between the valves of the two taxa. Candona alchichica $n$. sp. has taller valves $(P<0.05)$, with concave dorsal margin, and with the anterior margin considerably narrower than posterior margin, all characteristics different from $\mathrm{C}$. patzcuaro. Most important, in spite of their similar shape, the two species exhibit contrasting ecological preferences. Candona alchichica $n$. sp. inhabits clear, cold, saline, oligotrophic waters, whereas C. patzcuaro dwells in turbid, warm, fresh, eutrophic waters. In addition, we include a revision of the morphological characteristics and taxonomic position of C. patzcuaro, based on type material and specimens collected from the type locality (i.e., Lake Pátzcuaro, Michoacán). This study highlights the importance of undertaking detailed morphometric analyses of the recent ostracod fauna to provide reliable taxonomic identifications and ecological characterizations of species, which are critical for accurate paleoclimatic and paleoecological reconstructions.
\end{abstract}

Key words: Ostracods; taxonomy; morphometry; ecology; Puebla.

Received: April 2016. Accepted: September 2016.

\section{INTRODUCTION}

Cypridoidea Baird, 1845 is the largest superfamily within freshwater ostracods (Martens and Savatenalinton, 2011; Karanovic, 2012), it encompasses more than $80 \%$ of the known diversity in these environments (Martens et al., 2008). Recent molecular evidence suggested that Cypridoidea is integrated by six families (Hiruta et al., 2016): Candonidae Kaufmann, 1900, Cyclocyprididae Kaufmann, 1900, Cyprididae Baird, 1845, Ilyocyprididae Kaufmann, 1900, Notodromadidae Kaufmann, 1900 and Paracyprididae Sars, 1923. The family Candonidae is the second most speciose group (Martens et al., 1998; Karanovic, 2006; Martens and Savatenalinton, 2011), most probably originated during the Middle Jurassic (ca. 150 $\mathrm{Ma}$ ) when Cypridoidea experienced an explosive radia- tion (Smith and Delorme, 2010). Currently, Candonidae encompasses a single subfamily, Candoninae Kaufmann, 1900, eight tribes, 39 genera and more than 400 species distributed worldwide (Martens and Savatenalinton, 2011; Karanovic, 2012). Candoninae species are characterized by variable size and shell morphology, but all of them lack swimming setae on the second antenna, indicating their benthic life (Meisch, 2000; Karanovic, 2005; Karanovic and Datry, 2009). The species may display broad ecological tolerances, allowing them to colonize a variety of habitats across a broad geographic range. Candona candida (O.F. Müller, 1776), for example, is currently recorded in Europe and North America (Meisch, 1996, 2000; Karanovic, 2006). In contrast, quite a number of endemic species of Candoninae have been recorded as well, possessing distributions limited to an ecoregion or 
even a single lake (Delorme, 1970; Karanovic, 2003, 2005; Higuti and Martens, 2014). In North America, 40 extant Candoninae species have been described so far, out of which $65 \%$ are endemic (Karanovic, 2006). In this region, most of the species recorded belong to the genus Candona Baird, 1845 (Karanovic, 2006). In Canada and the United States Candona species are distributed across a broad range of aquatic ecosystems, but in lakes, they are found predominantly in the littoral zone, where sediments are rich in organic matter and oxygen concentrations are low (Tressler, 1947; Delorme, 1970; Boyd, 1981; Meisch, 2000; Karanovic, 2006). Candona candida, however, have been found down to depths of $300 \mathrm{~m}$ in Loch Morar, Scotland (Griffiths and Martin, 1993). Some species of the genus are considered permanent residents in deep water habitats, where temperature does not exceed $18^{\circ} \mathrm{C}$ (Niinemets, 1999), and occasionally they have been found inhabiting anaerobic environments and groundwater (Boyd, 1981; Meisch, 2000).

In Mexico, the Candoninae subfamily is still poorly known and only eight species have been recorded: Candona caudata Kaufmann, 1900 (Palacios-Fest et al., 2002), Candona hipolitensis Tressler, 1954 (Tressler, 1954), Candona michoa Tressler, 1954 (Tressler, 1954), Candona patzcuaro Tressler, 1954 (Tressler, 1954; Forester, 1985; Bridgwater et al., 1999; Garduño-Monroy et al., 2011; Chávez-Lara et al., 2012, 2015), Fabaeformiscandona rawsoni Tressler 1957=Eucandona obtusa (Bronstein 1947) (Maddocks et al., 2009), Pseudocandona punctata (Furtos, 1933) (Czaja et al., 2014), and Fabaeformiscandona acuminata (Fischer, 1854) (Pérez et al., 2015), all of them from centralnorthern Mexico, whereas just one, Pseudocandona antilliana, has been found in the southern part of the country (Cohuo et al., 2016).

Most reports in Mexico came from Quaternary deposits and Holocene sediment sequences, in which species identification relied mainly on shell morphology. Candona patzcuaro, C. michoa, F. acuminata and P. antilliana are the only species in which taxonomic identification was conducted using soft parts and carapace morphology. The frequent occurrence of this group of species in the fossil record in Mexico thus, highlights the importance of gathering ecological information and establish a robust taxonomy on modern taxa, with the ultimate goal of providing accurate paleoenvironmental reconstructions.

Previous studies of benthic invertebrates in Lake Alchichica revealed the presence of ostracods in the littoral, sublittoral (Hernández et al., 2010) and profundal zones (Hernández et al., 2014). Among them, the recently described Limnocytherina axalapasco Cohuo-Durán, Pérez \& Karanovic, 2014 was found in the shallow littoral area of Lake Alchichica (Cohuo-Durán et al., 2014). Further surveys in this lake revealed the presence of another ostracod belonging to the genus Candona. Here we provide a detailed morphological description of $C$. alchichica n. sp., a new and most likely endemic species of ostracod that inhabits the saline Lake Alchichica, central Mexico. We also include information about its distribution in the lake, as well as habitat and ecological preferences. Additionally, we complemented the description of valves and male reproductive organs of $C$. patzcuaro not included in the original description, based on type material and specimens collected from the type locality (i.e., Lake Pátzcuaro, Michoacán), and we also provide a brief assay about its taxonomic position within Candoninae.

\section{STUDY AREA}

Lake Alchichica $\left(19^{\circ} 24.7^{\prime} \mathrm{N}, 97^{\circ} 24.0^{\prime} \mathrm{W}\right.$, Fig. 1) is a maar lake located in the endorheic Oriental drainage basin $\left(4982 \mathrm{~km}^{2}\right)$ on the southeastern Central Mexican Plateau, near the borders of the states of Puebla, Veracruz and Tlaxcala (Alcocer et al., 2000; Filonov et al., 2006). Climate in the region is semi-arid, with an average temperature of $12.9^{\circ} \mathrm{C}$, annual rainfall of $<500 \mathrm{~mm}$ and a potential evapo-transpiration rate of $1690 \mathrm{~mm} \mathrm{y}^{-1}$ (Adame et al., 2008; Alcocer et al., 2000).

The lake has a surface area of $2.3 \mathrm{~km}^{2}$ (Fig. 1) and is nearly perfectly circular, with a shoreline length of $5.1 \mathrm{~km}$ and a diameter of $\sim 1.7 \mathrm{~km}$. Its greatest depth is $62 \mathrm{~m}$ and its average depth is $40.9 \mathrm{~m}$ (Filonov et al., 2006). It is a closed-basin lake with no surface inflows or outflows. The lake is mostly groundwater-fed. The saline (salinity $8.5 \pm 0.52 \mathrm{~g} \mathrm{~L}^{-1}$, conductivity $13 \pm 0.5 \mathrm{mS} \mathrm{cm}^{-1}$ ) and alkaline (pH 8.7-9.2) water is dominated by bicarbonate, chloride, sodium and magnesium ions (Vilaclara et al., 1993; Alcocer et al., 2000).

Alchichica is a warm monomictic lake that circulates during the cold dry season, from the end of December or beginning of January to the end of March or beginning of April. The lake remains stratified throughout the warm rainy season (Alcocer et al., 2000). The shape of the lake basin is almost cylindrical. It has a narrow littoral area surrounded by a discontinuous ring of stromatolites, and a very abrupt slope to depths of $50 \mathrm{~m}$. A flat plateau with gentle slope that ranges from 50 to $60 \mathrm{~m}$ depth occupies most of the bottom of the lake (Filonov et al., 2006).

\section{METHODS}

\section{Sampling and taxonomy}

Sampling was carried out monthly during the dry season, December 2010-March 2011, covering both the end of the stratification period and the onset of lake circulation, in both the littoral $(<5 \mathrm{~m})$ and the profundal $(>50 \mathrm{~m})$ zones. In situ water temperature, conductivity, dissolved oxygen 
concentration and $\mathrm{pH}$ were recorded with a DS4 Hydrolab multiprobe coupled to a SVR4 Hydrolab logging system. Sediment texture was determined following dry sieving for large particles (sand), and by pipetting wet samples for fine particles (silt and clay) (Folk, 1969). Particle size was characterized using the classification scale of Wentworth (Welch, 1948; Folk, 1969). Percent organic matter and carbonate $\left(\mathrm{CO}_{3}\right)$ in the sediment were determined from weight loss on ignition (LOI) at $550^{\circ} \mathrm{C}$ and $950^{\circ} \mathrm{C}$, respectively (Weber, 1973; Hammer et al., 1990). Sediment samples were collected from the littoral zone $(0.5 \mathrm{~m})$ to the deepest part of the lake (50-62 m) (Fig. 1) with an Ekman dredge $\left(225 \mathrm{~cm}^{2}\right.$ surface area, $\left.15 \times 15 \times 15 \mathrm{~cm}\right)$. Samples were sieved in situ through a 0.51-mm pore-size mesh (Gray, 1981; Wetzel, 1981). Samples were preserved with $96 \%$ ethanol and transported to the laboratory.

Adult specimens were sorted under a Leica stereomicroscope. Forty specimens (20 females and 20 males) with well-preserved soft parts were dissected. Soft parts were mounted on microscope slides in Hydromatrix mounting media. Non-dissected material was preserved in plastic tubes with $70 \%$ ethanol. All original samples were deposited at El Colegio de la Frontera Sur, Chetumal Unit (ECOSUR). A Nikon light microscope was used to characterize the species with the aid of a camera lucida. SEM photographs were taken for right and left valve of eight individuals using a Jeol JSM-5600LV LCM scanning microscope in the Central Microscopy Laboratory, Institute of Physics and with a Hitachi SU1510 scanning microscope in the Institute of Biology, Universidad Nacional Autónoma de México (UNAM), Mexico.

Systematics of the Candoninae subfamily follow Karanovic (2006, 2012), except for Candona patzcuaro (named Eucandona patzcuaro in Karanovic, 2012). For this species, the incomplete taxonomic information provided in the original descriptions challenge its accurate classification within Candonidae. Therefore, anticipating the results of the species revision carried out in this study, we refer to this species as Candona patzcuaro instead Eucandona patzcuaro (see Discussion).

Terminology for appendages A1, Md, Mxl, L5 and L6 follows Broodbakker and Danielopol (1982), whereas we

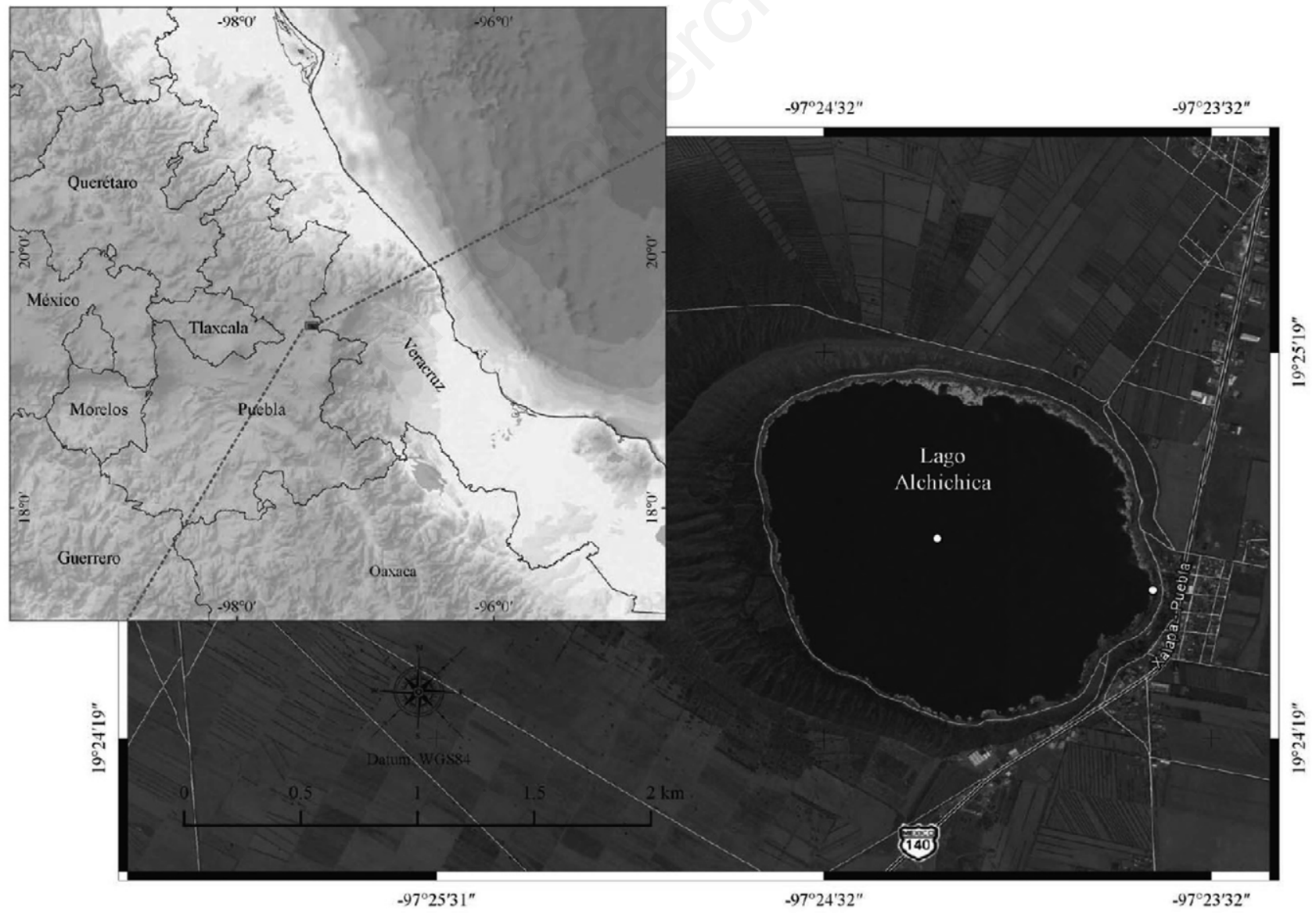

Fig. 1. Satellite image of Lake Alchichica, Mexico. White dots indicate sampling sites. 
followed Meisch (1996) for the L7. Terminology for A2 follows Martens (1987), after revision of the original nomenclature provided by Broodbakker and Danielopol (1982). Regarding A2, because of the position of the terminal claws, the short one in males is considered to be homologous with the female GM claw, whereas the long one is homologous with the female Gm claw. Lobes on the hemipenis are labeled according to Danielopol (1969). Setal classification follows Garm (2004). Abbreviations used in the text and figure captions are, in alphabetical order: A1, antennula; A2, antenna; LV, left valve; L5, L6, L7, first, second and third thoracopods, respectively; Md, mandible; Mdp, mandibular palp; Mx, maxilla; RV, right valve; UR, uropodal ramus.

\section{Morphometric analysis}

Following the keys presented by Karanovic (2006, 2012), and original descriptions of species distributed in the region, we observed that the species with higher valve similarities with Lake Alchichica ostracods were Candona patzcuaro. In spite of the similarities between these two species, the Lake Alchichica ostracods did not exactly match the $C$. patzcuaro description, suggesting they may represent a new species. Careful analysis of the shell dimensions of both the C. patzcuaro and Alchichica ostracods thus needed to be undertaken.

For C. patzcuaro, the morphological description of valves is poor therefore the type material of this species was requested from the Smithsonian Institution-NMNH to obtain a more complete characterization than that provided by Tressler (1954) in the original description. Unfortunately, the C. patzcuaro type material is in poor condition. Nevertheless, Dr. Rose A. Gulledge was kind enough to send us photographs that enabled us to measure and compare the type specimens of $C$. patzcuaro with the ostracods from Lake Alchichica. Additionally, we carried out two field visits (July 2013 and February 2014) to Lake Pátzcuaro, Michoacán (the type locality), to obtain $C$. patzcuaro specimens for comparison with the Lake Alchichica animals. Unfortunately, we obtained only isolated valves and carapaces of adult males and females, but not a single living or dead organism with preserved soft parts.

Morphometric analysis of ostracod valves was therefore conducted on both species using organisms collected by us. The right and left valves of 40 individuals $(\mathrm{n}=20$ females and $\mathrm{n}=20$ males) belonging to Alchichica species and $C$. patzcuaro, were measured with an ocular micrometer (10X). Each data series was $\log$ transformed $[\log 10(\mathrm{n}+1)]$ and its normality and homogeneity were tested. We ran t-student and non-parametric Mann-Whitney U tests to detect significant differences between valve dimensions of the studied communities from Lakes Alchichica and Pátzcuaro. The software SPSS (version 18.0) was used for statistical analyses.

\section{RESULTS}

\section{Systematics (according Karanovic 2006, 2012)}

Order Podocopida Sars, 1866

Family Candonidae Kaufmann, 1900

Subfamily Candoninae Kaufmann, 1900

Genus Candona Baird, 1845

Diagnosis (after Karanovic, 2006, 2012): LV always overlaps RV. Carapace subtriangular, subreniform or subtrapezoidal. Valve surface usually covered with thickened pore lips from which setae originate. Calcified inner lamella narrow. A1 7-segmented. Most posterior seta on the penultimate segment of A1 present. A2 sexually dimorphic, in the male the endopod is 4-segmented and carries two sexual bristles (transformed t-setae). Terminal claws G1 and G3 are reduced, z2-seta is transformed into a claw, z1-seta clawlike or seta-like, but always much longer than terminal segment and z3 always seta-like. Protopod in female is 3 -segmented. Md palp 4-segmented, second segment internally with $5+1,4+2$ or $5+2$ setae. L5 in males with hooklike or elongated palps. L6 5-segmented with the basal segment carrying one seta. L7 4- or 5-segmented. Basal segment with two setae (d1 and dp) and terminal segment with $\mathrm{h} 2$ and $\mathrm{h} 3$ setae long, while h1 seta short, but never shorter than the terminal segment itself. UR with both claws and both setae present. Posterior seta always reaches at least the distal end of posterior margin, and is usually much longer. On hemipenis, the part ' $\mathrm{g}$ ' is well sclerified and all three lobes are present. Zenker organ with seven whorls of spines. Female genital lobe with or without extension.

Candona alchichica sp. nov. (Figs. 2-7)

Material examined. Holotype: male dissected on one slide (ECO-CH-Z-07792). Allotype: female dissected on one slide (ECO-CH-Z-07794). Paratype: one male (ECO$\mathrm{CH}-\mathrm{Z}-07793)$ and one female (ECO-CH-Z-07795) dissected on separate slides.

Other material: two males (ECO-CH-Z-07796, ECOCH-Z-07797) and one female (ECO-CH-Z-07798) from the type locality, dissected on separate slides.

Type locality. Lake Alchichica $19^{\circ} 24.7^{\prime} \mathrm{N}, 97^{\circ} 24.0^{\prime}$ W, Puebla, Mexico.

Etymology. This species is named after Lake Alchichica, where the species was collected in high abundances. The name should be treated as a noun in apposition.

Differential diagnosis: medium-size ostracod slightly exceeding one $\mathrm{mm}$ in length. Dorsal margin somewhat rounded, gently sloping toward anterior end, steeply sloping toward posterior end. Greatest height at around the last third of the shell. Anterior margin narrowly rounded, posterior margin distinctly more broadly rounded. Marginal pore canals straight. Male valves with a small triangular projection around the mouth region. Valve surface with 
thickened pore lips from which seta originate. A2 sexually dimorphic, in males the z1 and z2 setae claw-like. Second segment of mdp with $5+1$ setae. Male prehensile palps asymmetrical, the right one stout and arched, the left one is slightly elongated. Both palps have a hook-like appearance and two long projections. Fingers are positioned at $90^{\circ}$ with respect to the palp. UR straight, with posterior claw exceeding half the length of the anterior claw. Hemipenis with g-structure well sclerotized and exceeding the distal end of b-lobe. Lobe 'a' with a small pointed projection at the base. Lobe ' $h$ ' distally square-shaped. Female genital field with a long digitiform process.

Description of male: Carapace in lateral view subtrapezoidal (Figs. 2 A,B and 3 A,B). Valves asymmetrical, LV overlapping RV anteriorly, posteriorly and ventrally (Fig. 3 E,F). Valves with dorsal margin slightly rounded, posteriorly more distinctly sloping than anteriorly (Fig. 2). Greatest height at around the posteriormost third of the shell. Anterior margin narrowly rounded, and slightly projected downwards. Posterior margin broadly rounded. Ventral margin concave around the first third of the shell and with a small projection at the mouth region, more pronounced in LV than in RV. Calcified inner lamella shorter posteriorly than anteriorly, anteriorly equaling $9.6 \%$ and posteriorly $3.8 \%$ of total length of the valve (Figs. 2 C,D and 3 C,D). Marginal pore canals straight, hairs more abundant anteriorly than posteriorly. Muscle scar imprints consist of six grouped scars and two additional elongated ones more anteriorly (Fig. 3C). Valve surface smooth, but covered with abundant thickened pore lips from which setae originate. Length of valves: $L V=1.23 \mathrm{~mm}, \mathrm{RV}=1.12 \mathrm{~mm}$.
A1 (Fig. 4A). 7-segmented. First segment (CB) anteriorly with two serrulate setae; postero-distally with two unequally long setae, longer one serrulate and reaching the distal end of fifth segment. Second segment with one antero-apical smooth seta that exceeds the end of the penultimate segment. Third segment carries a single apical smooth seta that reaches the proximal end of the terminal segment. Fourth segment with two long and smooth setae antero-distally; postero-distally on the same segment, one relatively short apical seta that does not reach the distal end of the penultimate segment. Fifth segment antero-distally with two long and bare setae; postero-distally with one short seta, not reaching the distal end of terminal segment. Sixth segment with five smooth and long setae of unequal length, all of which far exceed the distal end of the terminal segment. Terminal segment carries three unequally long setae and the aesthetasc $y a$, which is 1.9 times longer than the segment that carries it. Length ratios of the last five segments are as follows: 0.4: 0.9: 0.8: 1.1: 1 .

A2 (Fig. 4 B,C). 6-segmented. Coxa carries two setae distally, the shorter one hairy. Basis postero-distally with one long and bare seta that just exceeds the distal end of following segment. Exopod (Ex) is reduced to a plate with one long and two small setae. Longer seta reaches the distal end of the following segment. First endopodal segment with aesthetasc Y, 1.3 times as long as the terminal segment. Postero-distally on the same segment, two long and bare setae exceed the distal end of terminal segment. Second endopodal segment with aesthetasc $y 2$ relatively short. On distal end, the three t-setae are present. Seta t1, thin and relatively short, just reaching the distal end of following segment. Setae $\mathrm{t} 2$ and $\mathrm{t} 3$ transformed into sex-

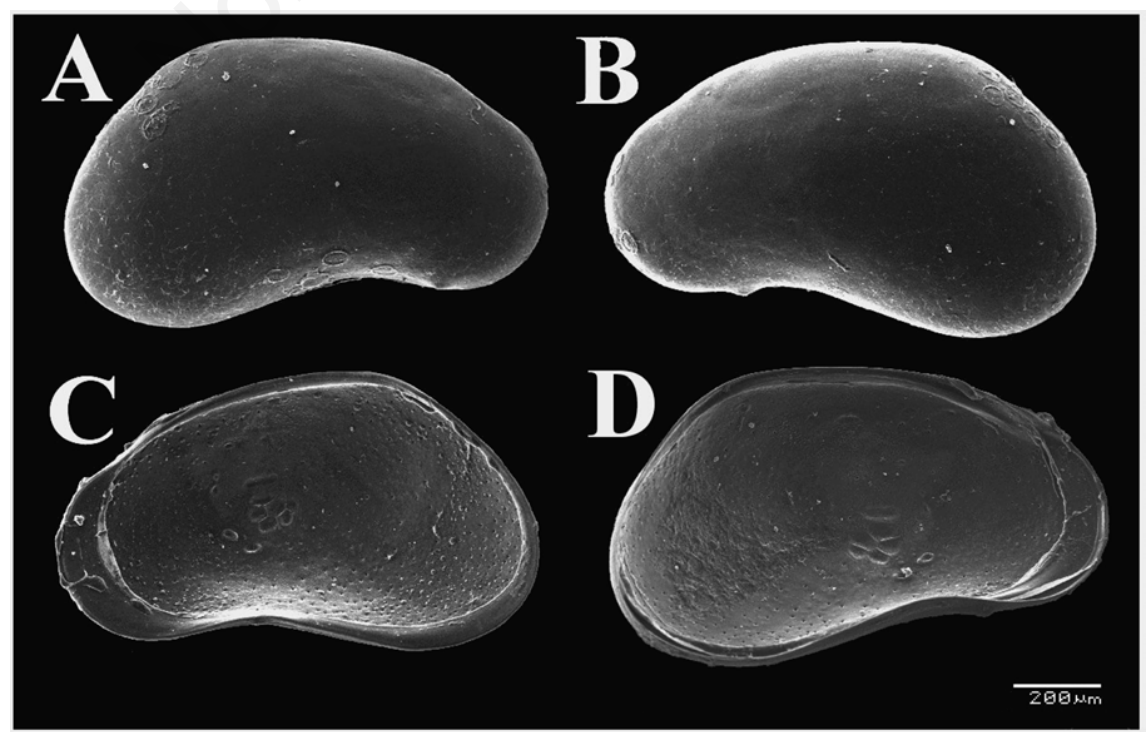

Fig. 2. SEM of male Candona alchichica n. sp. A) RV external view; B) LV external view; C) RV internal view; D) LV internal view. 
ual bristles. Both bristles end with a triangular structure and exceed the distal end of the terminal segment. Third endopodal segment with the three $\mathrm{z}$-setae present. Setae $\mathrm{z} 1$ and z2 transformed into long and strong claws, whereas $z 3$ is seta-like, just exceeding the distal end of the terminal segment. Claws G1 and G2 strong and distally slightly serrate. G1 claw is 5.1 times longer than terminal segment, whereas G2 is 6.2 longer than the same segment. Claw G3 transformed into a seta, which is thin and 3.4 times longer than the terminal segment. Fourth endopodal segment (terminal segment) carries the claws GM and Gm, which differ in length, Gm almost reaching the tip of G2, whereas GM is short, equaling 2.8 times the length of the segment that carries it. Both claws are distally serrate. Aesthetasc $y 3$ is slender and two times longer than the terminal segment.
Md palp 4-segmented (Fig. 4D). First segment with four setae. Most proximal seta is long and serrulate and it exceeds by far the distal end of terminal segment. Seta S1 long and pappose, seta S2 short and basally widened, $\alpha$ seta slender, smooth and relatively long, overpassing the distal end of following segment. Second segment with setal group consisting of $5+1$ setae. Seta $\beta$ thin and slender. Ventero-distally on this same segment, two bare and subequally long setae are present. Third segment carries six distally serrulate setae. Seta $\gamma$ relatively slender and by far exceeding the distal end of terminal segment. Fourth segment (terminal segment) almost equally long as wide and carries two claw-like setae and two thin setae.

Mxl (Fig. 4E). Palp 2-segmented. First segment elongated and carries four apical long and bare setae. Terminal segment almost equally long as wide and carries five ter-
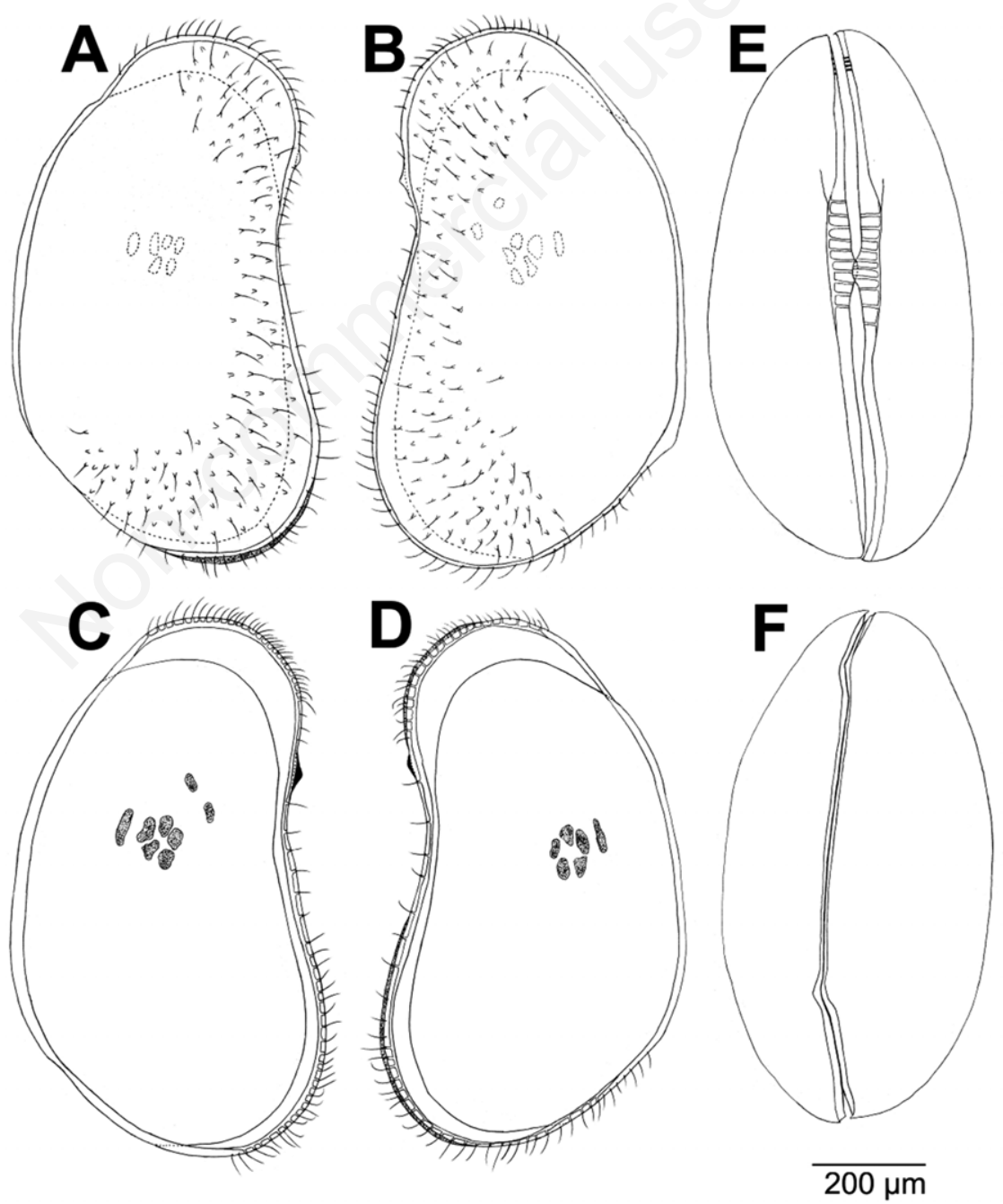

Fig. 3. Candona alchichica n. sp. male. A) RV external view; B) LV external view; C) LV internal view; D) RV internal view; E) Carapace ventral view; F) Carapace dorsal view. 
minal setae, the central one being strong and narrowly fused with the segment. Third endite with six terminal setae. Second endite with seven terminal setae. First endite with nine setae, longer one serrulate. Two additional setae are present on the base of this endite, the shorter one being serrulate.

L5 (Fig. 5A, B). Palp asymmetrical, right one (Fig. 5A) stocky with the dorsal margin sinusoid and with two well-developed sub-terminal projections. Finger wide with a hook-like appearance positioned at around $90^{\circ}$ with respect to the palp. Left palp (Fig. 5B) smaller than the right one, with the finger compressed and positioned at $90^{\circ}$ with respect to the palp. Two long and one short subterminal projections are present. Protopodite apically with nine subequally long setae and three serrulate subterminal setae. Setae a, b and d present.

L6 (Fig. 5C). 5-segmented. Basal segment with one bare seta (d1). First endopodal segment slightly hirsute and with a relatively long and serrulate e-seta. Second endopodal segment with f-seta exceeding the distal end of following segment. Third endopodal segment with g-seta long, by far overpassing the distal end of the terminal segment. Terminal segment with a long claw (h2) and two lateral short setae (h1 and h3). Distal claw equals the length of last three segments combined.

L7 (Fig. 5D). 4-segmented. Basal segment with d1 and dp setae long and serrulate. Second segment bare. Third segment with g-seta thin and by far exceeding the distal end of the terminal segment. Fourth segment (terminal segment) with h2-seta serrulate and elongated, 10.3 longer than the segment that carries it. Seta h1 serrulate and two-thirds the length of seta h2. Seta h3 setae 9.4 times as long as the terminal segment.

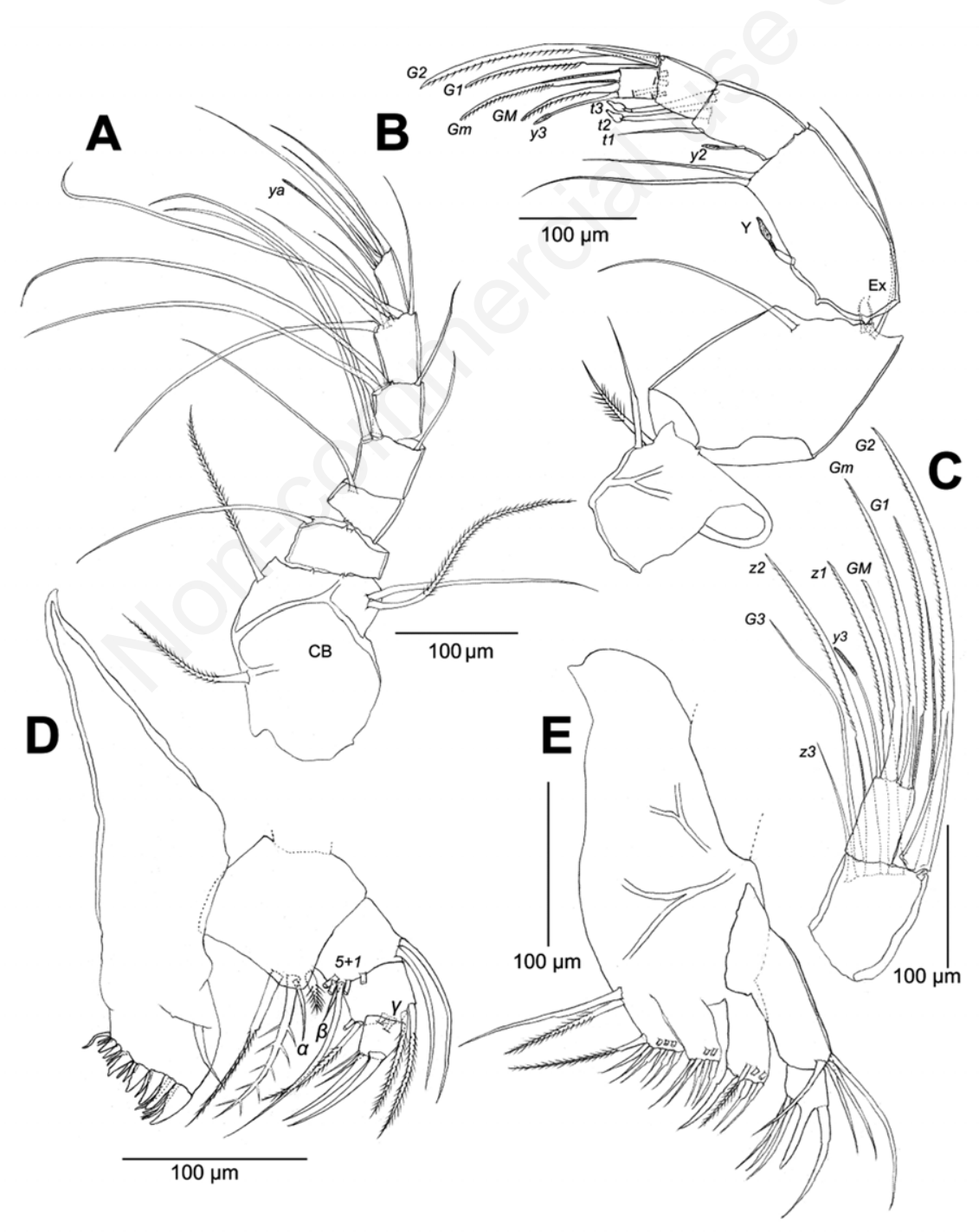

Fig. 4. Candona alchichica n. sp. male. A) A1; B) A2; C) detail of last two segments of A2; D) Md and mdp; E) maxilla and mxp. 
UR (Fig. 5F). Ramus straight. Anterior claw distally serrate and reaching the middle of the ramus. Anterior seta short and smooth, equaling one fifth of the anterior claw. Posterior claw slightly curved and distally serrated, reaching two fifths the length of the ramus. Posterior seta smooth and slightly smaller than posterior claw. UR attachment (Fig. 5E) elongated and distally bifurcated.

Hemipenis (Fig. 5G). Lobe 'a' elliptical with blunt tip, basally with an elongated digitiform projection. Medial lobe (' $b$ ' lobe) well-sclerotized with evenly rounded distal margin. Lobe ' $h$ ' narrow and elongated with a squarish shape at distal margin. Part ' $\mathrm{g}$ ' well-sclerotized and exceeding the distal end of the medial lobe. The tip has a boxing glove appearance. Zenker organ with seven whorls of spines.

Description of female: Carapace slightly smaller than male (Figs. 6 A,B and 7 A,B). Dorsal margin is slightly rounded with the greatest height at the last third of the shell (Fig. 6 A,B). Postero-dorsally the margin slopes steeply, forming a small depression (Fig. 7 A,B). Anterior margin narrowly rounded and slightly projected downward. Posterior margin square in shape and broader than the anterior margin. On ventral margin the triangular projection in the mouth region is absent. Calcified inner lamella (Fig. 7C, D) slightly differing in length from male. Anteriorly equaling $9.6 \%$ and posteriorly $6.7 \%$ of total length of the valve. Muscle scar imprints as in males, consisting of five grouped scars (Fig. 6D; 7C), most posterior ones, elongated. Valve surface mostly smooth, but with a net reticulation close to the margins (Fig. 6C). Valves overlap as in male.

Carapace size: $\mathrm{LV}=1.12 \mathrm{~mm}$ and $\mathrm{RV}=1.09 \mathrm{~mm}$.

A1. Similar to that of the male with exception of the two anterior setae in the fourth, and five segment, which are shorter than in male.

A2 (Fig. 7E). 5- segmented. Coxa with apical setae shorter than in males, the shorter one is hairy. The basis and first endopodal segment similar to male. On the second endopodal segment all four t-setae present, and extending beyond the distal end of the terminal segment.
Only two z-seta were observed, both short and slender, not reaching the half-length of distal claws. G1 and G3 claw strong and elongated five times as long as terminal segment. Claw G2 reduced, equaling three times the length of terminal segment. Postero-distally on this same segment the aesthetasc $y 2$ is short. Third endopodal segment (terminal segment) with GM almost reaching the tip of both G1 and G3 claws, whereas Gm smaller, equaling 3.3 times the length of terminal segment. Aesthetasc $y a$ short and accompanied by one seta which is thin and relatively short. Md, Mxl as in male.

L5 (Fig. 7F). Endopodite hirsute with three serrulate and subequally long setae. Exopodite consisting of two rays. Protopodite with setae 'a', 'b' and 'd' present. Apically with ten smooth or serrulate seta and four additional sub-terminal setae.

L6 (Fig. 7G) and L7 (Fig. 7H) as in male.

UR and genital process (Fig. 7I). Ramus slightly curved. Anterior claw slightly exceeding half the length of the ramus. Anterior seta short, reaching one fifth of the adjacent claw. Posterior claw curved, shorter than half the length of the ramus. Posterior seta slightly smaller than the anterior claw. Genital field with a finger-shaped projection with the last third widened and a pointed tip. Genital process equaling $55 \%$ of the length of the ramus.

\section{Candona alchichica n. sp. and C. patzcuaro shell morphometry}

Candona alchichica n. sp. resembles C. patzcuaro in carapace morphology, making it difficult to distinguish the two taxa using valves only. To clarify the taxonomic position of C. alchichica n. sp., and identify characters that can be used to distinguish between the two putative taxa when appendages are lacking, a morphometric analysis of both species was conducted. Because $C$. alchichica n. sp. displays sexual dimorphism, morphometric analyses were conducted separately for male and female adult specimens. The C. alchichica n. sp. male LV shows a mean length of $1.23 \pm 0.04 \mathrm{~mm}$, but the difference between the smallest and largest specimen analyzed was $\sim 0.15 \mathrm{~mm}$ (Tab. 1). Similarly, the RV was about $1.19 \pm 0.05 \mathrm{~mm}$ in

Tab. 1. Candona alchichica n. sp. valve dimensions ( $\mathrm{mm}$ ) of adult males and females from Lake Alchichica.

\begin{tabular}{|c|c|c|c|c|c|}
\hline \multirow[t]{2}{*}{ C. alchichica } & \multirow[t]{2}{*}{ Variable } & \multicolumn{2}{|c|}{ Left valve } & \multicolumn{2}{|c|}{ Right valve } \\
\hline & & Mean \pm SD & Range & Mean \pm SD & Range \\
\hline \multirow[t]{3}{*}{ Males } & Length & $1.23 \pm 0.04$ & $1.18-1.33$ & $1.19 \pm 0.05$ & $1.04-1.26$ \\
\hline & Height & $0.69 \pm 0.03$ & $0.64-0.78$ & $0.67 \pm 0.02$ & $0.63-0.71$ \\
\hline & Width & $0.37 \pm 0.02$ & $0.33-0.42$ & $0.32 \pm 0.03$ & $0.28-0.36$ \\
\hline \multirow[t]{3}{*}{ Females } & Length & $1.17 \pm 0.05$ & $1.11-1.25$ & $1.14 \pm 0.05$ & $1.07-1.23$ \\
\hline & Height & $0.66 \pm 0.02$ & $0.62-0.70$ & $0.64 \pm 0.02$ & $0.61-0.69$ \\
\hline & Width & $0.35 \pm 0.02$ & $0.33-0.40$ & $0.34 \pm 0.01$ & $0.31-0.35$ \\
\hline
\end{tabular}


mean length and the difference in valve length between the largest and smallest specimen was about $0.22 \mathrm{~mm}$ (Tab. 1). In the case of females, mean LV length was $1.17 \pm 0.05 \mathrm{~mm}$, and mean RV length was $1.14 \pm 0.05 \mathrm{~mm}$. Female specimens showed a maximum size difference of $0.16 \mathrm{~mm}$ between the largest and smallest measured individuals from the population.

Candona patzcuaro also showed sexual dimorphism, with female specimens being smaller than males (Figs. 8 and 9). In males, LV $(1.27 \pm 0.03 \mathrm{~mm})$ is slightly larger than RV $(1.25 \pm 0.03 \mathrm{~mm})$ and the former overlaps the latter anteriorly and posteriorly. The difference in valve length was about $0.13 \mathrm{~mm}$ (Tab. 2). Female LV was about
$1.14 \pm 0.02 \mathrm{~mm}$ average length and RV was $1.11 \pm 0.02 \mathrm{~mm}$. The difference between the smallest and largest specimen of the population was only $0.08 \mathrm{~mm}$ (Tab. 2).

Comparison of the two species showed the length and width of both right and left valves of $C$. patzcuaro males are larger $(\mathrm{P}<0.05)$ than those of $C$. alchichica n. sp. In contrast, the right and left valves of $C$. alchichica $\mathrm{n}$. sp. males are taller $(\mathrm{P}<0.05)$ than those of $C$. patzcuaro males. In the case of females, the right and left valves of C. alchichica n. sp. are significantly longer and taller $(\mathrm{P}<0.05)$ than those of $C$. patzcuaro. The right valve of C. alchichica $\mathrm{n}$. sp. is wider $(\mathrm{P}<0.05)$ than that of $C$. patzcuaro females as well.

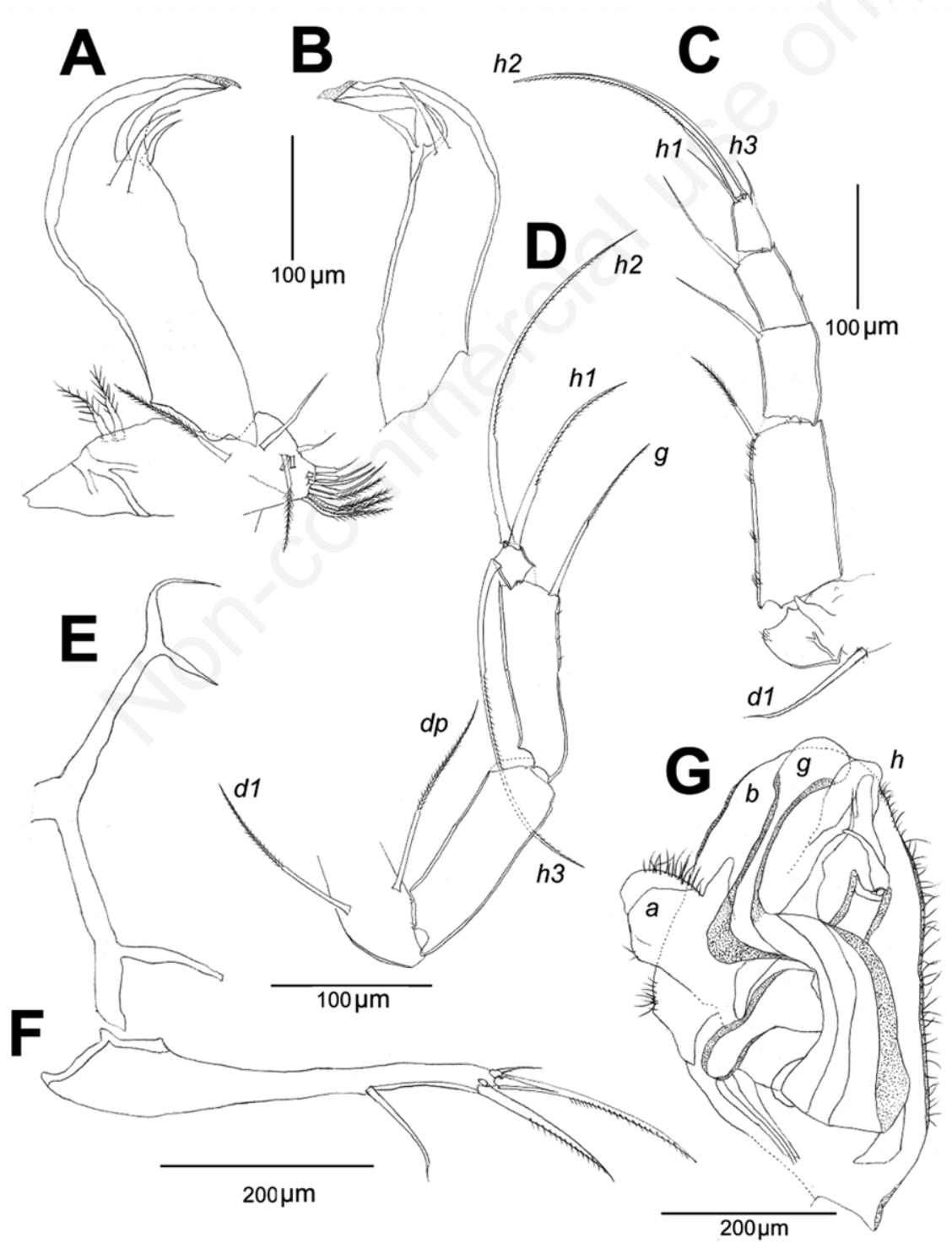

Fig. 5. Candona alchichica n. sp. male. A) Right prehensile palp with protopodite; B) left prehensile palp; C) L6; D) L7; E) UR attachment; F) UR; G) hemipenis. 


\section{Candona alchichica $\mathbf{n}$. sp.: distribution and habitat}

Candona alchichica $\mathrm{n}$. sp. is most likely a benthic species because it was observed dwelling exclusively in the sediments and among aquatic plants. It inhabits areas of the lake from the shallow littoral zone, where waters are warm and well oxygenated, to the deepest portion of the lake at $62 \mathrm{~m}$, where waters are cold and anoxic for 79 months of the year (Hernández et al., 2014). In the littoral zone, but not in the deep zone, C. alchichica n. sp. co-occurs with another ostracod species, Limnocytherina axalapasco Cohuo, Pérez \& Karanovic 2014.

The environmental range where $C$. alchichica n. sp. was collected is presented in Tab. 3. Conductivity and $\mathrm{pH}$ values display a narrow range compared to the other water variables such as temperature and dissolved oxygen. In contrast, sediment composition varies widely, from low to high concentrations of organic matter and sediment carbonate content (Tab. 3). This species was found to inhabit both sandy and muddy sediments.

\section{DISCUSSION}

\section{Candona alchichica n. sp. morphological affinities}

Candona alchichica $\mathrm{n}$. sp. belongs to the acuminata group of species because on the second segment of the mdp, the setal group consists of $5+1$ setae, the male prehensile palps have a hook-like appearance, and in females, the genital process is well developed. The acuminata group of Candona currently has 34 species distributed worldwide (Karanovic, 2006, 2012), out of which C. tahoensis Ferguson, 1966 and C. ohioensis Furtos, 1933 are closely related to $C$. alchichica n. sp. Candona patzcuaro, despite is not included in the acuminata group, mostly because of the absence of detailed morphological description of the soft parts, showed the closest relationship with the new species, particularly with respect to shell morphology. All species mentioned above share the following characteristics: prehensile palps hook-like, posterior margins in female valves slightly inclined, female genital process finger-shaped, and in the male hemipenis, lobe ' $a$ ' is inclined, not reaching the distal end of lobe ' $b$ '.

Candona alchichica n. sp., differs from C. tahoensis in the following characteristics: the latter species has rectangular-shaped valves, the male prehensile palps are robust and elongated, and on the hemipenis the a-lobe lacks a basal projection, the h-lobe extends beyond the distal end of the b-lobe, and the ' $g$ ' part ends in a foot-shaped structure, all characteristics different from those of the Mexican species.

Candona alchichica n. sp. differs from C. ohioensis in that the left prehensile palp of the latter species has a well-chitinized bump on the ventral part of the finger, which is absent in C. alchichica n. sp. Additionally the hemipenis of $C$. alchichica $\mathrm{n}$. sp. has the ' $\mathrm{g}$ ' part ending in a boxing-glove-like structure, whereas it is foot-shaped

Tab. 2. Candona patzcuaro valve dimensions $(\mathrm{mm})$ of adult males and females of Lake Pátzcuaro.

\begin{tabular}{|c|c|c|c|c|c|}
\hline \multirow[t]{2}{*}{ C. patzcuaro } & \multirow[t]{2}{*}{ Variable } & \multicolumn{2}{|c|}{ Left valve } & \multicolumn{2}{|c|}{ Right valve } \\
\hline & & Mean \pm SD & Range & Mean \pm SD & Range \\
\hline \multirow[t]{3}{*}{ Males } & Length & $1.27 \pm 0.03$ & $1.20-1.33$ & $1.25 \pm 0.03$ & $1.17-1.30$ \\
\hline & Height & $0.66 \pm 0.02$ & $0.63-0.70$ & $0.63 \pm 0.02$ & $0.61-0.65$ \\
\hline & Width & $0.42 \pm 0.08$ & $0.32-0.47$ & $0.38 \pm 0.06$ & $0.28-0.40$ \\
\hline \multirow[t]{3}{*}{ Females } & Length & $1.14 \pm 0.02$ & $1.10-1.18$ & $1.11 \pm 0.02$ & $1.08-1.15$ \\
\hline & Height & $0.58 \pm 0.02$ & $0.53-0.62$ & $0.56 \pm 0.01$ & $0.54-0.58$ \\
\hline & Width & $0.35 \pm 0.04$ & $0.27-0.41$ & $0.31 \pm 0.02$ & $0.25-0.34$ \\
\hline
\end{tabular}

Tab. 3. Average values ( \pm standard deviation) and ranges of environmental variables of Lake Alchichica, Puebla, where Candona alchichica n. sp. was collected.

\begin{tabular}{lcccccccc} 
Zone & $\begin{array}{c}\text { Temp } \\
\left({ }^{\circ} \mathrm{C}\right)\end{array}$ & $\begin{array}{c}\text { Cond } \\
\left(\mathrm{mS} \mathrm{cm}^{-1}\right)\end{array}$ & $\begin{array}{c}\mathrm{DO} \\
\left(\mathrm{mg} \mathrm{L}^{-1}\right)\end{array}$ & & $\mathrm{pH}$ & $\mathrm{CO}_{3}$ & Text \\
\multirow{2}{*}{ Littoral } & $20.7 \pm 1.0$ & $12.6 \pm 0.6$ & $8.3 \pm 1.6$ & $9.0 \pm 0.0$ & $5.6 \pm 3.6$ & $11.2 \pm 1.7$ & $1.4 \pm 0.0$ \\
\hline \multirow{2}{*}{ Profundal } & $18.3-24.9$ & $11.0-13.2$ & $6.5-12.3$ & $8.9-9.0$ & $2.8-8.4$ & $1.9-29$ & $0.2-2.3$ \\
& $14.5 \pm 0.1$ & $13.6 \pm 0.7$ & $3.9 \pm 1.1$ & $9.2 \pm 0.1$ & $34.7 \pm 3.5$ & $13.6 \pm 3.7$ & $5.9 \pm 1.2$ \\
& $14.4-14.6$ & $11.9-14.5$ & $0-5.3$ & $8.9-9.6$ & $29-36$ & $6-15$ & $3-9$ \\
\hline
\end{tabular}

Temp, temperature; Cond, electrical conductivity; DO, dissolved oxygen; $\mathrm{pH}$, hydrogen potential; $\mathrm{OM}$, sediment organic matter; $\mathrm{CO}_{3}$, sediment carbonates; Text, sediment texture. 
in $C$. ohioensis. Lobe ' $a$ ' in $C$. ohioensis also lacks the basal projection observed in C. alchichica n. sp.

Candona alchichica $\mathrm{n}$. sp. and C. patzcuaro are very similar in carapace and soft part morphology. In soft parts, the lobes of the hemipenis have similar positions and lengths, and the a-lobe in both species has the digitiform projection at the base (Figs. $5 \mathrm{G}$ and $10 \mathrm{C}, \mathrm{G}$ ). Furthermore, the male valves of both species have the small triangular projection around the mouth region (Figs. 2 A,B and 8 $\mathrm{A}, \mathrm{B}, \mathrm{E})$. The main differences in soft part between them are however, as follows: C. alchichica n. sp. has on the male prehensile palps the fingers more robust and elongated. They are narrowly positioned with respect to the palp (Fig. 5 A,B). Candona patzcuaro male prehensile palps, however, have thinner fingers, well separated from the palp (Fig. 10D). On the hemipenis of C. alchichica n. sp., the b-lobe is distally rounded and the h-lobe elongated, extending beyond the distal end of the b-lobe (Fig. $5 \mathrm{G})$. In contrast, C. patzcuaro hemipenis has the lobe ' $b$ ' slightly pointed and the h-lobe does not extend beyond the distal end of the b-lobe (Fig. 10 C,G).

In regard to valves, the size variability of both $C$. alchichica and C. patzcuaro indicates that specimen length can overlap, making it difficult to differentiate between species based on shell size alone. Thus, additional characters, such as height of the shells, must be considered to discriminate between them. Candona alchichica n. sp. has significantly higher shells than C. patzcuaro, in both male and female specimens. Candona alchichica n. sp. also has valves compressed, with the dorsal margins slightly rounded (Figs. 2 and 6). The anterior margin is considerably narrower than the posterior margin which is broadly rounded and projects downward (Figs. 2 and 8). In contrast valves of $C$. patzcuaro are more rectangular and elongate, with dorsal margins flat (Figs. 8 and 9). Anterior and posterior margins are almost the same width (Figs. 8 and 9).

In regard to $C$. michoa, which is currently considered as synonym of $C$. patzcuaro, the most divergent characteristics with $C$. alchichica n. sp. are the valve shape and length. In C. michoa dorsal margin are flat and gently sloping upward toward posterior end, while in C. alchichica n. sp. the dorsal margin is rounded with a steep sloping upward. Valves are similar in length, C. michoa is around 1.16 $\mathrm{mm}$ and $C$. alchichica $\mathrm{n}$. sp. is $1.17 \pm 0.05 \mathrm{~mm}$, but they differ in height. Candona alchichica n. sp. valves are taller $(0.66 \pm 0.02)$ than $C$. michoa valves $(0.58 \mathrm{~mm})$. Other differences can be found in L7, setae h2 and h3 are equal in length in C. michoa but in C. alchichica n. sp. h3 is smaller than h2 seta. In the UR terminal claw in C. alchichica n. sp. exceeds half length of the ramus, whereas in C. michoa the same claw just reach the half length of the ramus.

\section{Taxonomic position of $C$. patzcuaro and $C$. michoa}

The definitive taxonomic position of Candona patzcuaro is still under discussion because both males and

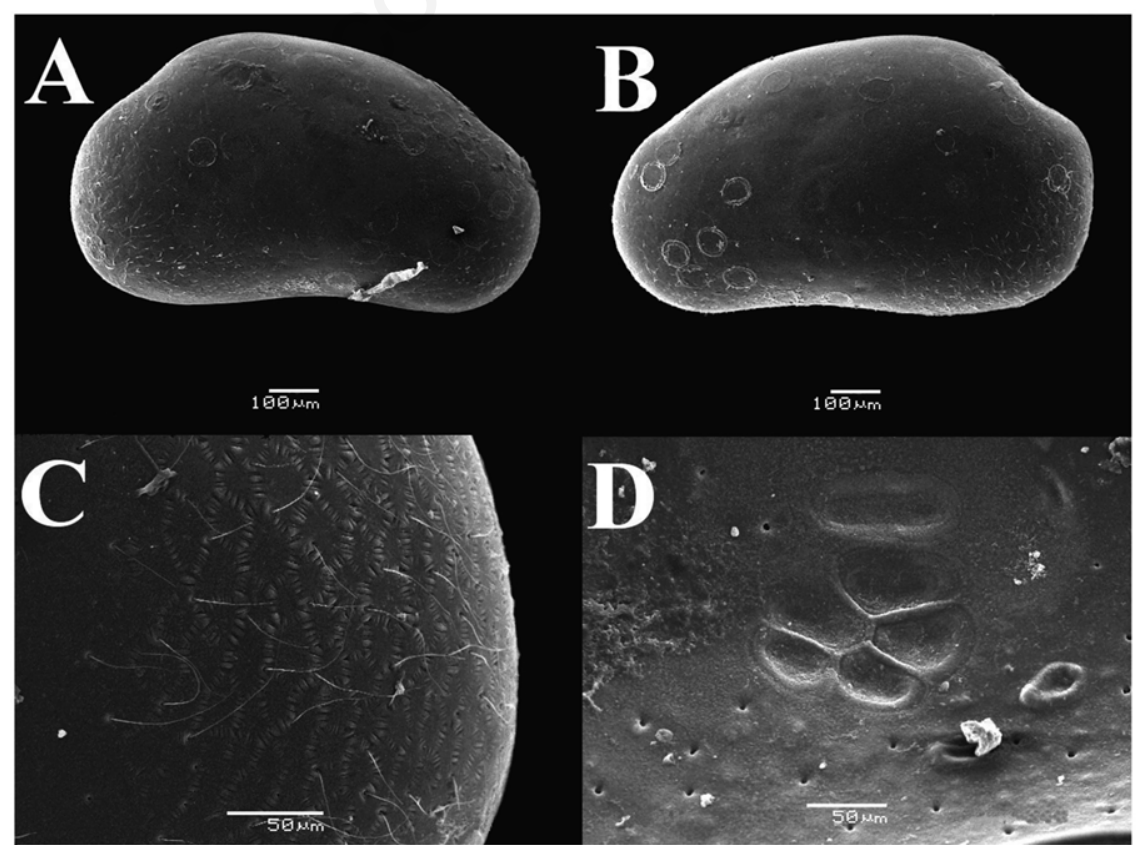

Fig. 6. SEM of female Candona alchichica n. sp. A) RV external view; B) LV external view; C) detail of surface ornamentation; D) detail of muscle scars. 
females are poorly described and illustrated. As a result, it is possible to find in the literature divergent descriptions and broad ecological tolerances attributed to this species. Delorme (1970) reported that it has a broad geographic distribution, because he found it across the southern Canadian prairies. He also provided a characterization of the species, based on pictures of the shell and soft parts of the Canadian specimens. Karanovic (2006) used this characterization to compare C. patzcuaro with other North American species. She concluded that there was not enough evidence to retain it as distinct taxon, and concluded it was synonymous with Eucandona obtusa Bronstein, 1947, E. michoa Tressler, 1954 and E. rawsoni Tressler, 1957. Later, Martens and Savatenalinton (2011) in their checklist of the freshwater ostracod fauna of the world retained the C. patzcuaro as valid taxon, but transferred it to the genus Fabaeformiscandona. They did not, however, provide any taxonomic information to support this change. Finally, Karanovic (2012) reconsidered $C$. patzcuaro as valid, but she included it in the genus $E u$ candona and proposed that E. michoa was a synonym of this species. In this study, we use the name Candona patzcuaro for this species, because although we were not able to study all soft parts, appendages from the type specimens of C. patzcuaro, particularly the male reproductive organs (Fig. 10 C,D,G) show higher affinities with the genus Candona than with Fabaeformiscandona or Eucandona e.g., Candona patzcuaro has hook-like shaped palps, contrary to Fabaeformiscandona and on hemipenis the lobe ' $\mathrm{h}$ ' is present, contrary to Eucandona (Karanovic,

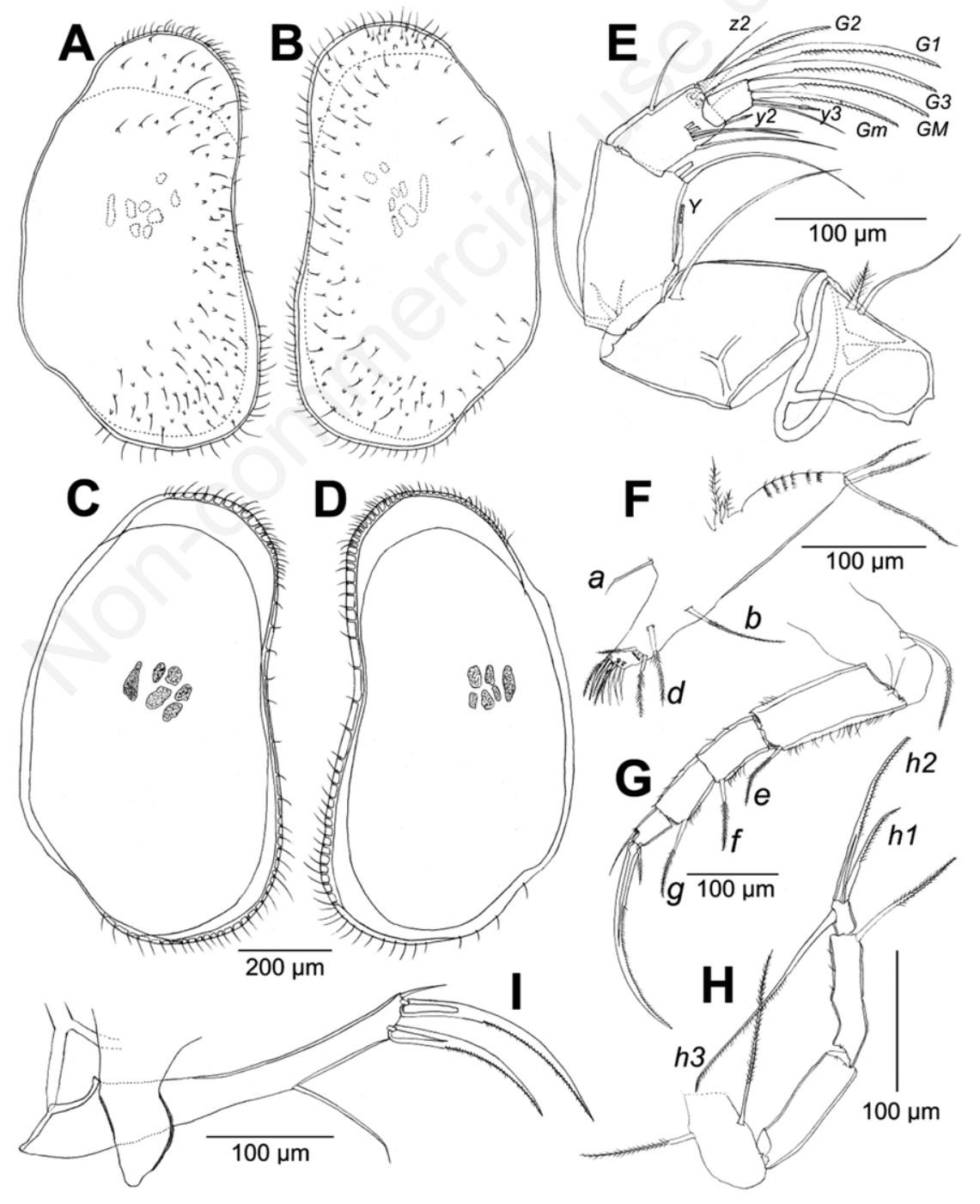

Fig. 7. Candona alchichica $n$. sp. female. A) RV external view; B) LV external view; C) LV internal view; D) RV internal view; E) A2; F) L5; G) L6; H) L7; I) UR and female genital field. 
2006). This classification is however provisional and a detailed taxonomic analysis of the species is needed. We also found that photographs of the southwestern Canadian specimens provided by Delorme (1970) enable differentiation from the $C$. patzcuaro type specimen, especially pictures of the reproductive organs, which suggest that they are, in fact, different species. The hemipenis in $C$. patzcuaro sensu Delorme (1970) has the b-lobe much elongated and pointed, the a-lobe is centrally positioned, and the prehensile palps have the fingers largely elongated. In contrast type specimens of C. patzcuaro has a short b-lobe that is broadly rounded at the distal end and the a-lobe is laterally positioned, with a small projection at the base and with the distal end rounded (Fig. 10C). We thus distinguish between Candona patzcuaro and the Canadian species, but leave the taxonomic assignment of the latter species open for now.

We also observed that Candona michoa valves are highly similar to the female valves of $C$. patzcuaro reported in this study for both length and height. They also display similar shape, particularly in regard of the dorsal margin. In addition, the fact that the two species were described from the same lake and that in the description of C. patzcuaro female lacks, we consider that $C$. michoa may represent the female form of C. patzcuaro. We therefore keep C. michoa as synonym of C. patzcuaro, but still the revision of the type material of these two species is required to test this hypothesis.

\section{Comparative ecology of $C$. alchichica $\mathrm{n}$. sp. and $C$. patzcuaro}

Candona alchichica n. sp. and C. patzcuaro reside in Lakes Alchichica and Pátzcuaro, respectively, both located in the region known as the trans-Mexican volcanic belt. According to Alcocer and Bernal-Brooks (2010) the lakes are located at the same latitude $\left(19^{\circ} \mathrm{N}\right)$ and similar altitudes (Pátzcuaro=2035 m; Alchichica $=2300 \mathrm{~m}$ ); however, Lake Pátzcuaro is large (18 km long, $8.4 \mathrm{~km}$ wide, $90 \mathrm{~km}^{2}$ surface area) and shallow (9.4 m and $4.9 \mathrm{~m}$, maximum and

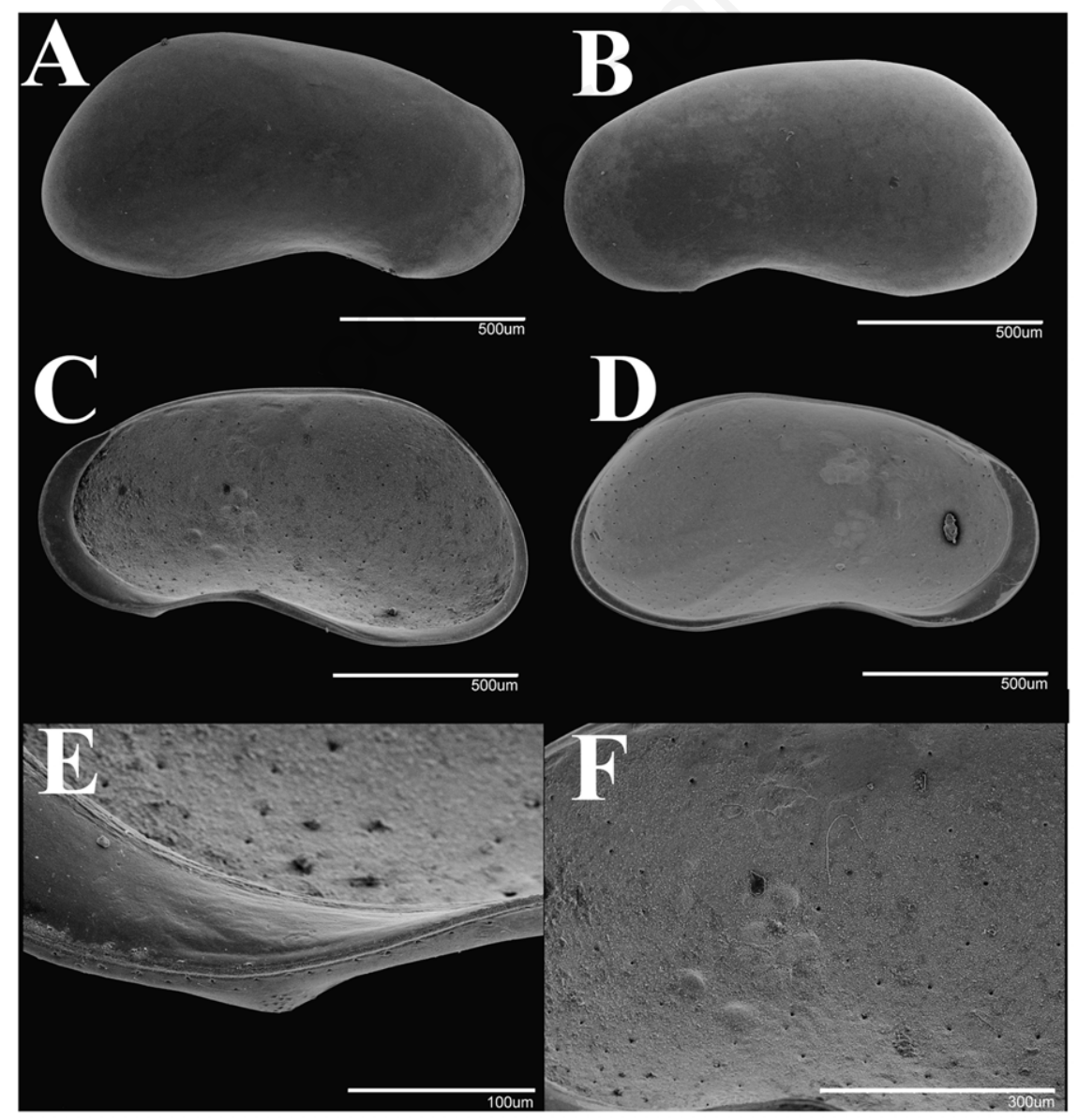

Fig. 8. SEM of Candona patzcuaro male specimen from Lake Pátzcuaro. A) RV external view; B) LV external view; C) RV internal view; D) LV internal view; E) detail of ventral projection at mouth region; F) detail of internal pore canals. 
mean depth, respectively), whereas Lake Alchichica is small (1.8 km diameter, $2.3 \mathrm{~km}^{2}$ surface area) and deep (62 $\mathrm{m}$ and $40.9 \mathrm{~m}$ maximum and mean depth, respectively). Pátzcuaro is a freshwater lake $\left(\mathrm{K}_{25}=0.3-1.0 \mathrm{mS} \mathrm{cm}{ }^{-1}\right.$; $\left.\mathrm{TDS}=0.5 \mathrm{~g} \mathrm{~L}^{-1}\right)$ with calcium bicarbonate $\left[\mathrm{Ca}\left(\mathrm{HCO}_{3}\right)_{2}\right]$ water, whereas Alchichica is a saline lake $\left(\mathrm{K}_{25}=12.8 \mathrm{mS}\right.$ $\mathrm{cm}^{-1}$; TDS $\left.=8.86 \mathrm{~g} \mathrm{~L}^{-1}\right)$ with sodium chloride $(\mathrm{NaCl})$ water. Lake Pátzcuaro is warm polymictic, turbid $\left(\mathrm{Z}_{\mathrm{SD}}=0.1-0.5 \mathrm{~m}\right)$ and eutrophic $\left(\mathrm{Chl}-a=59.8 \mathrm{mg} \mathrm{m}^{-3}\right)$; conversely, Lake Alchichica is warm monomictic, clear $\left(\mathrm{Z}_{\mathrm{SD}}=5 \mathrm{~m}\right)$ and oligotrophic (Chl- $a=0.2-2.2 \mathrm{mg} \mathrm{m}^{-3}$ ). This highlights that the two aquatic ecosystems display different limnological properties, which probably accounts for the presence of two different species.

Candona patzcuaro inhabits the shallow littoral area $(\leq 1 \mathrm{~m})$, with coarse sediments dominated by clayey sand that is rich in organic matter (plant detritus), and where there are abundant macrophytes. The water was turbid, warm and poorly oxygenated. Candona alchichica n. sp. inhabits depths from the shallow littoral area down to the deepest portion of the lake $(62 \mathrm{~m})$, suggesting a tolerance of a broad range of environmental variables. The littoral area where the species was found is sandy and rich in organic matter, and it is covered with macrophytes (i.e., Zoostera marina and Cyperus laevigatus) and benthic algae (Ramirez-Garcia and Novelo, 1984). The deep benthic zone has fine sediments dominated by clayey silts with high organic matter content (algae detritus); higher aquatic plants are absent in the aphotic depths. The water is clear, with temperatures varying from comparatively warm $\left(18-25^{\circ} \mathrm{C}\right)$ in the littoral, to cold (down to $14^{\circ} \mathrm{C}$ ) in the deep part of the lake. Dissolved oxygen content was also variable ranging from $6.5-9.1 \mathrm{mg} \mathrm{L}^{-1}$ in the littoral, but from only $6.5 \mathrm{mg} \mathrm{L}^{-1}$ during the circulation period (January-March) to anoxic during the period of stable stratification (April-December) (Alcocer and BernalBrooks, 2010).

\section{Distribution of $C$. alchichica n. sp. and C. patzcuaro}

As far as we know, the geographic range of $C$. alchichica n. sp. is restricted to Lake Alchichica. Thus, the extinction risk evaluation method for the wildlife in Mexico (abbreviated MER in Spanish), partially based on Gärdenfors et al. (2001), results to be very restricted. This category applies to micro-endemic species with limited distributions in Mexico ( $<5 \%$ of the Mexican territory). Lake Alchichica qualifies for this category because its surface area is about $2.3 \mathrm{~km}^{2}$, representing $\sim 0.0001 \%$ of the Mexican territory $\left(1.96 \times 10^{6} \mathrm{~km}^{2}\right)$.

Candona alchichica $\mathrm{n}$. sp. is here therefore suggested as the $8^{\text {th }}$ endemic species described for Lake Alchichica, which include the diaptomid copepod Leptodiaptomus garciai (Osorio-Tafall, 1942; Montiel-Martínez et al., 2008), the atherinid fish Poblana alchichica (De Buen, 1945), the hemipteran Krizousacorixa tolteca (Jansson, 1979), the

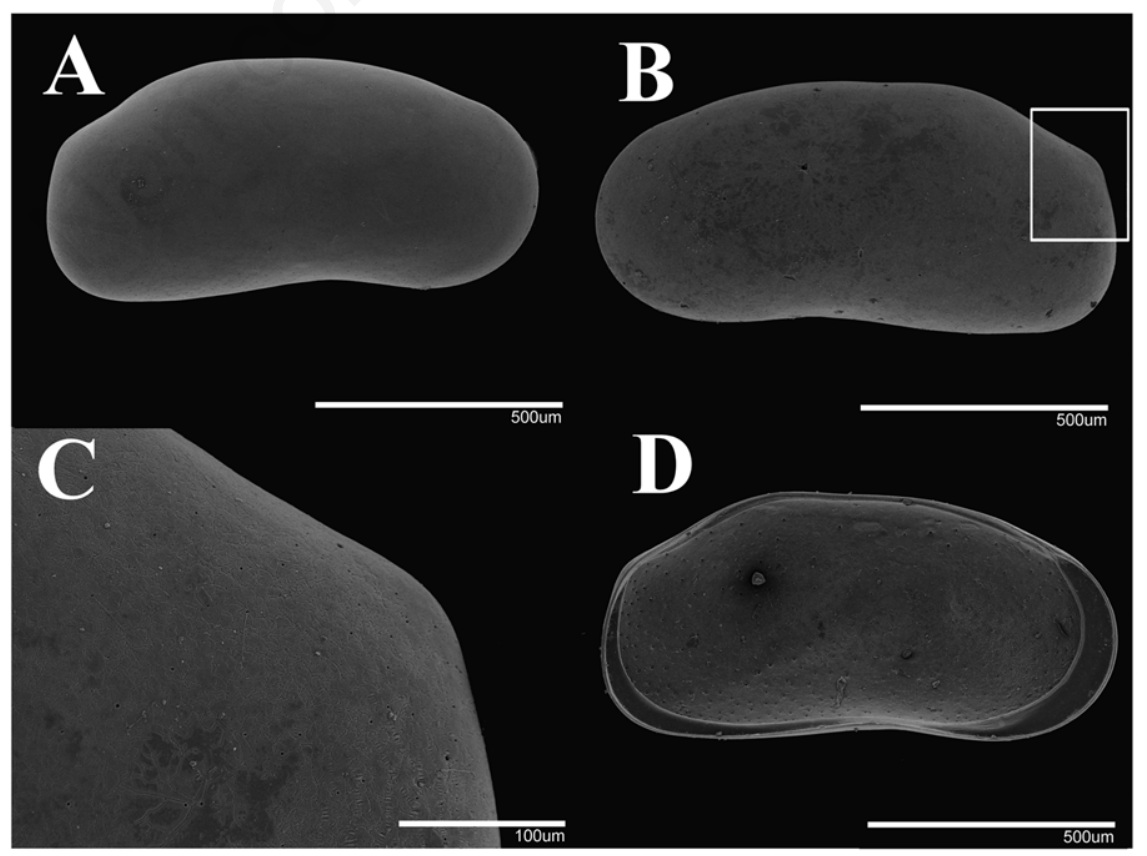

Fig. 9. SEM of Candona patzcuaro female specimen from Lake Pátzcuaro. A) RV external view; B) LV external view; C) detail of dorso-posterior margin; D) LV internal view. 
salamander Ambystoma taylorii (Brandon et al., 1981), the isopod Caecidotea williamsi (Escobar-Briones and Alcocer, 2002), the diatom Cyclotella alchichicana (Oliva et al., 2006), and the harpacticoid copepod Cletocamptus gomezi (Suárez-Morales et al., 2013).

Candona patzcuaro contrastingly was previously considered as widely distributed throughout the Nearctic region (Tressler, 1954; Delorme, 1970). Our study, however, suggests that the distribution of this species might be more restricted than previously thought, because species considered to be $C$. patzcuaro from Canada were probably misidentified. Therefore a careful analysis of the distribution ranges and ecological preferences of this species is required, particularly because of its frequent use as paleobioindicators of past climate change in the region.

\section{CONCLUSIONS}

Candona alchichica n. sp. is a new ostracod species that appears to be endemic to Lake Alchichica, Puebla, Mexico. The taxonomic analysis revealed its affinity with the North American fauna, and in particular, it showed close morphological relationship with $C$. patzcuaro, $C$. tahoensis and C. ohioensis. Nevertheless, C. alchichica n. sp. differs from these species in that the prehensile palps are compressed, with the fingers positioned at $90^{\circ}$ with respect to the palp, the hemipenis has the a-lobe inclined with a projection at the base, and the g-structure ends with a boxing-glove shape. In females, the genital field has a digitiform projection, wide at the middle and narrow at the end. Morphometric analysis of Candona alchichica n. sp. and C. patzcuaro shells showed that in spite of their overall size and shape similarities, several specific characteristics serve to distinguish between them, C. patzcuaro possesses slightly smaller female and slightly larger male shells compared to C. alchichica n. sp. and valves of $C$. alchichica n. sp. are taller than those of $C$. patzcuaro. These characteristics are important, especially if no soft parts are preserved.

Ecologically, Candona alchichica n. sp. inhabits saline, $\mathrm{NaCl}$ waters, which are alkaline, oligotrophic, relatively cold, and transparent, as in Lake Alchichica. It is a benthic species that inhabits areas from the littoral zone to the greatest depths of the profundal zone $(62 \mathrm{~m})$, in sandy and muddy sediments that are rich in organic matter, vegetated or bare substrate.

This study highlights the importance of reliable, detailed identification of ostracods to species level, particularly if valve remains in sediments are to be used for paleoecological and paleoclimate inference. Candona alchichica n. sp. and C. patzcuaro valves are morphologically similar, but they display radically different ecological preferences. Thus, misidentification of these species could confound data interpretations and lead to erroneous paleoenvironmental inferences.

\section{ACKNOWLEDGMENTS}

Special thanks to Rose A. Gulledge from the Smithsonian Institution-NMNH for her support and pictures of $C$.

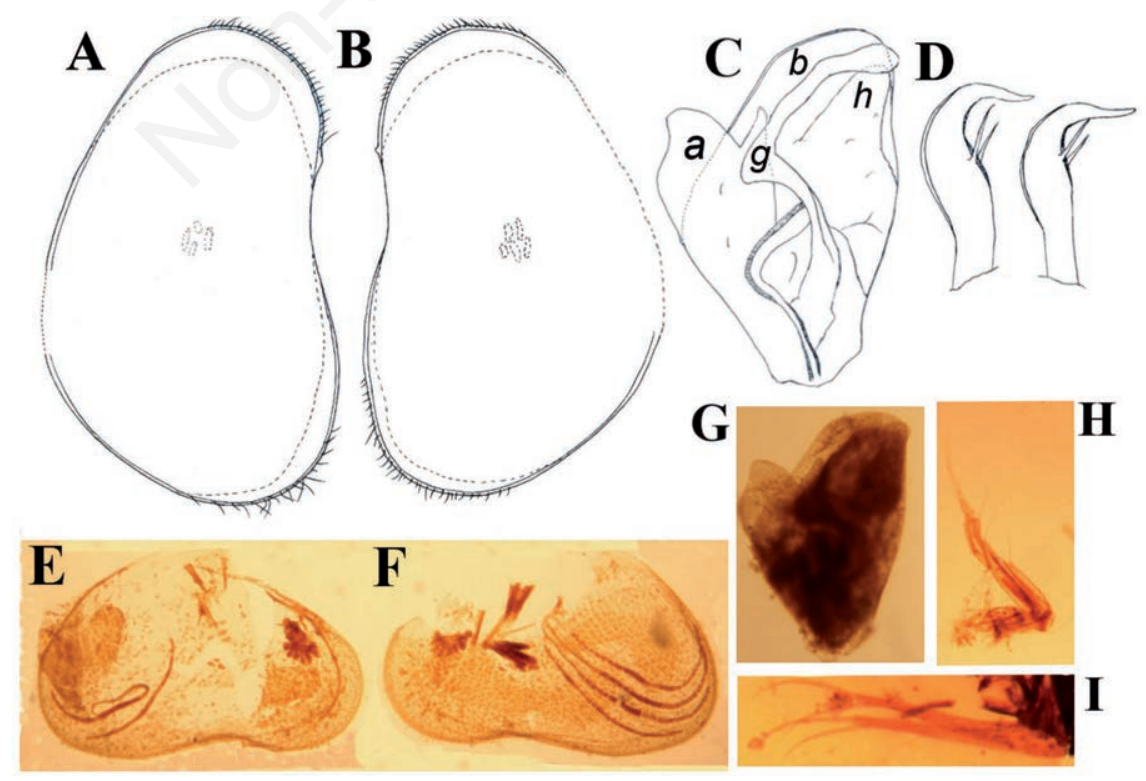

Fig. 10. Candona patzcuaro (type material) male. A, E) RV external view; B, F) LV external view; C, G) hemipenis; D) male prehensile palps; H) L6; I) UR. Drawings and pictures not to scale. 
patzcuaro type specimens. Our sincere gratitude to M.Sc. Berenit Gonzáles from the Laboratory of Microscopy and Photography of Biodiversity, Institute of Biology, UNAM, Mexico, and to Anais Cisneros and Fernanda Charqueño for assistance in taking the SEM pictures. We are grateful to Mark Brenner for detailed English editing and suggestions. The following agencies and institutions provided financial support: CONACYT (projects 167621 \& 103332), CONACYT project 190519 provide funds for SEM analysis, DGAPA-PAPIIT (project IN215512), UNAM FES Iztacala (project PAPCA 2013), National Science Foundation (NSF award number 0902864), and the Institute of Geology, UNAM. CONACYT also provided scholarships for the first and second authors.

\section{REFERENCES}

Adame MF, Alcocer J, Escobar E, 2008. Size-fractionated phytoplankton biomass and its implications for the dynamics of an oligotrophic tropical lake. Freshwater Biol. 53:22-31.

Alcocer J, Bernal-Brooks FW, 2010. Limnology in Mexico. Hydrobiologia 644:15-68.

Alcocer J, Lugo A, Escobar E, Sánchez MR, Vilaclara G, 2000. Water column stratification and its implications in the tropical warm monomictic Lake Alchichica, Puebla, México. Verh. Internat. Verein. Theor. Angew. Limnol. 27:3166-3169.

Boyd PD, 1981. The micropalaeontology and palaeoecology of medieval estuarine sediments from the Fleet and Thames in London, p. 274-292. In: J.W. Neale and M.D. Basier (eds.), Microfossilis from recent and fossil shelf seas. Ellis-Horwood, Chicester.

Brandon RA, Maruska EJ, Rumph WT, 1981. A new species of neotenic Ambystoma (Amphibia, Caudata) endemic to Laguna Alchichica, Puebla, Mexico. Bull. Southern California Acad. Sci. 80:112-125.

Bridgwater N, Heaton T, O'Hara S, 1999. A late Holocene paleolimnological record from central Mexico, based on faunal and stable-isotope analysis of ostracod shells. J. Paleolimnol. 22:383-397.

Broodbakker NW, Danielopol DL, 1982. The chaetotaxy of Cypridacea (Crustacea, Ostracoda) limbs: proposal for a descriptive model. Bijdr. Dierkd. 52:103-120.

Chávez-Lara C, Priyadarsi R, Caballero M, Carreño AL, Lakshumanan C, 2012. Lacustrine ostracodes from the Chihuahuan Desert of Mexico and inferred Late Quaternary paleoecological conditions. Rev. Mex. Cienc. Geol. 29:422-431.

Chávez-Lara C, Roy P, Pérez L, Sankar G, Lemus V, 2015. Ostracode and $\mathrm{C} / \mathrm{N}$ based paleoecological record from Santiaguillo basin of subtropical Mexico over last 27 cal kyr BP. Rev. Mex. Cienc. Geol. 32:1-10.

Cohuo-Durán S, Pérez L, Karanovic I, 2014. On Limnocytherina axalapasco, a new freshwater ostracod (Podocopida: Limnocytheridae) from Mexican crater lakes. Rev. Biol. Trop. 62:15-32.

Cohuo S, Macario-González L, Pérez L, Schwalb A, 2016. Overview of Neotropical-Caribbean freshwater ostracode fauna (Crustacea, Ostracoda): identifying areas of endemism and assessing biogeographical affinities. Hydrobiologia 1:17.
Czaja A, Palacios-Fest M, Estrada-Rodríguez J, Romero U, Alba J, 2014. Inland dunes fauna and flora from Paleolake Irritila in the Comarca Lagunera, Coahuila, northern Mexico. Bol. Soc. Geol. Mexicana 66:541-551.

Danielopol DL, 1969. [Notes sur la morphologie et la systématique de la sous-famille Limnocytherinae Sars (Crustacea, Ostracoda)].[Article in French]. Ann. Speleol. 24:129-142.

De Buen F, 1945. Investigaciones sobre ictiología mexicana. I. Atherinidae de aguas continentales de México. An. Inst. Biol. Univ. Nal. Autón. Méx. XVI:475-532.

Delorme LD, 1970. Freshwater ostracodes of Canada. Part III. Family Candonidae. Can. J. Zool. 48:1099-1127.

Escobar-Briones E, Alcocer J, 2002. Caecidotea williamsi (Crustacea: Isopoda: Asellidae), a new species from a saline crater-lake in the eastern Mexican Plateau. Hydrobiologia 477:93-105.

Filonov A, Tereshchenko I, Alcocer J, 2006. Dynamic response to mountain breeze circulation in Alchichica, a crater lake in Mexico. Geophys. Res Lett. 33:L07404.

Folk RL, 1969. [Petrología de rocas sedimentarias].[Book in Spanish]. Universidad Nacional Autónoma de México: 405 pp.

Forester R, 1985. Limnocythere bradburyi n. sp.: A modern ostracode from Central Mexico and a possible Quaternary paleoclimatic indicator. J. Paleontol. 59:8-20.

Gärdenfors U, Hilton-Taylor C, Mace G, Rodríguez M, Jon P, 2001. The application of IUCN Red List criteria at regional levels. Conserv. Biol. 15:1206-1212.

Garduño-Monroy V, Soria-Caballero D, Israde-Alcántara I, Hernández V, Rodríguez-Ramírez A, Ostroumov M, Rodríguez-Pascua M, Chacon-Torres A, Mora-Chaparro J, 2011. Evidence of tsunami events in the paleolimnological record of Lake Pátzcuaro, Michoacán, Mexico. Geofis. Int. 50:147-161.

Garm A, 2004. Revising the definition of the crustacean seta and setal classification systems based on examinations of the mouthpart setae of seven species of decapods, Zool. J. Linnean Soc. 142:233-252.

Gray JS, 1981. The ecology of marine sediments. Cambridge studies in modern biology. 2. Cambridge University Press. Cambridge: 185 pp.

Griffiths HI, Martin DS, 1993. The spatial distribution of benthic ostracods in the profundal zone of Loch Ness. Loch Ness and Morar Project. Scott. Nat. 105:137-147.

Hammer UT, Sheard JR, Kranabetter J, 1990. Distribution and abundance of littoral benthic fauna in Canadian prairie saline lakes. Hydrobiologia 197:173-192.

Hernández MC, Briones EE, Alcocer J, 2010. Ensamble de crustáceos bentónicos en un lago salino tropical. Rev. Mex. Biodivers. 81:133-140.

Hernández MC, Alcocer J, Oseguera LA, Escobar E, 2014. Profundal benthic invertebrates in an oligotrophic tropical lake: different strategies for coping with anoxia. J. Limnol. 73:387-399.

Higuti J, Martens K, 2014. Five new species of Candoninae (Crustacea, Ostracoda) from the alluvial valley of the upper Paraná River (Brazil, South America). Eur. J. Taxon. 106:1-36.

Hiruta S, Kobayashi N, Katoh T, Kajihara H, 2016. Molecular phylogeny of cypridoid freshwater Ostracoda (Crustacea: Ostracoda), inferred from $18 \mathrm{~S}$ and $28 \mathrm{~S}$ rDNA sequences. Zool. Sci. 33: 179-185. 
Jansson A, 1979. A new species of Krizousacorixa from Mexico (Heteroptera, Corixidae). Pan-Pac. Entomol. 55:258-260.

Karanovic I, 2003. A new genus of Candoninae (Crustacea, Ostracoda, Candonidae) from the subterranean waters of southwestem Western Australia. Rec. West. Aust. Mus. 21:315-332.

Karanovic I, 2005. Towards a revision of Candoninae (Crustacea: Ostracoda): Australian representatives of the subfamily, with descriptions of three new genera and seven new species. New Zeal. J. Mar. Fresh. 39:29-75.

Karanovic I, 2006. Recent Candoninae (Crustace, Ostracoda) of North America. Rec. West. Aust. Mus. Supplement No. 71.

Karanovic I, 2012. Recent freshwater ostracods of the world. Crustacea, Ostracoda, Podocopida. Springer, Berlin Heidelberg: 608 pp.

Karanovic I, Datry T, 2009. Overview of Candoninae (Crustacea, Ostracoda) of South America and the West Indies, with the description of two new species and one new genus. Zootaxa 2267:1-25.

Maddocks R, Machain-Castillo M, Gío-Argáez F, 2009. Podocopan Ostracoda (Crustacea) of the Gulf of Mexico, p. 877894. In: D.L. Felder and D.K. Camp (eds.), Gulf of Mexico - Origins, waters, and biota. Biodiversity. Texas A\&M Press, College.

Martens K, 1987. Homology and functional morphology of the sexual dimorphism in the antenna of Sclerocypris Sars, 1924 (Crustacea, Ostracoda, Megalocypridinae). Bijdr. Dierkd. 57:183-190.

Martens K, Horne DJ, Griffiths HI, 1998. Age and diversity of non-marine ostracods, p. 37-55. In: K. Martens (ed.), Sex and parthenogenesis: evolutionary ecology of reproductive modes in non-marine ostracods. Backhuys Publ., Leiden.

Martens K, Savatenalinton S, 2011. A subjective checklist of the recent, free-living, non-marine Ostracoda (Crustacea). Zootaxa 2855:1-79.

Martens K, Schön I, Meisch C, Horne D, 2008. Global diversity of ostracods (Ostracoda, Crustacea) in freshwater. Hydrobiologia 595:185-193.

Meisch C, 1996. Contribution to the taxonomy of Pseudocandona and four related genera, with the description of Schellencandona nov. gen., a list of the Candoninae genera, and a key to the European genera of the subfamily (Crustacea, Ostracoda). Bull. Soc. Nat. Luxemb. 97:211-237.

Meisch C, 2000. Freshwater Ostracoda of Western and Central Europe. Spektrum Akademischer Verlag, Heidelberg, Berlin: $522 \mathrm{pp}$.

Montiel-Martínez A, Ciros-Pérez J, Ortega-Mayagoitia E, ElíasGutiérrez M, 2008. Morphological, ecological, reproductivie and molecular evidence for Leptodiaptomus garciai (Osorio-Tafall 1942) as a valid endemic species. J. Plankton Res. 30:1079-1093.

Niinemets E, 1999. [Ostracode paleoecology and stable isotopes from Lake Peipsi, Estonia]. [Unpublished MSc Thesis]. Institute of Geology, University of Tartu, Estonia.

Oliva MG, Lugo A, Alcocer J, Cantoral-Uriza EA, 2006. Cyclotella alchichicana sp. nov. from a saline Mexican lake. Diatom Res. 21:81-89.

Osorio-Tafall BF, 1942. [Un nuevo Diaptomus del México Central (Copepoda, Diaptomidae)].[Article in Spanish]. Rev. Bras. Biol. 2:147-154.

Palacios-Fest M, Carreño AL, Ortega-Ramírez J, AlvaradoValdez G, 2002. A paleoenvironmental reconstruction of Laguna Babícora, Chihuahua, Mexico based on ostracode paleoecology and trace element shell chemistry. J. Paleolimnol. 27:185-206.

Pérez L, Lozano-García S, Caballero M, 2015. Non-marine ostracodes from highland lakes in East-central Mexico. Rev. Biol. Trop. 63:401-425.

Ramirez-Garcia P, Novelo A, 1984. [La vegetación acuática vascular de seis lagos- crater del estado Puebla, México].[Article in Spanish]. Bol. Soc. Bot. Méx. 46:75-88.

Smith A, Delorme D, 2010. Ostracoda, p. 725-771. In: H. James and A.P. Covich (eds.), Ecology and classification of North American freshwater invertebrates, 3rd ed. Academic Press, San Diego.

Suárez-Morales E, Barrera-Moreno O, Ciros-Pérez J, 2013. A new species of Cletocamptus Schmankewitsch, 1875 (Crustacea, Copepoda, Harpacticoida) from a high altitude saline lake in Central Mexico. J. Limnol. 72:313-325.

Tressler W, 1947. A check list of the known species of North American freshwater Ostracoda. Am. Midl. Nat. 38:698-707.

Tressler W, 1954. Fresh-water Ostracoda from Texas and Mexico. J. Wash. Acad. Sci. 44:138-149.

Vilaclara G, Chávez M, Lugo A, González H, Gaytán M, 1993. Comparative description of crater-lakes basic chemistry in Puebla State, Mexico. Verh. Internat. Verein. Limnol. 25: 435-440.

Weber CI, 1973. Biological field and laboratory methods for measuring the quality of surface waters and effluents. Macroinvertebrates. U.S. Environmental Protection Agency, Cincinnati: $38 \mathrm{pp}$.

Welch PS, 1948. Limnological methods. McGraw-Hill. New York: 381 pp.

Wetzel RG, 1981. [Limnología].[Book in Spanish]. Omega, Barcelona: $680 \mathrm{pp}$. 